\title{
Teachers' Perspectives on the Use of Differentiated Instruction in Inclusive Classrooms: Implication for Teacher Education
}

\author{
Charity Neejide Onyishi ${ }^{1,2} \&$ Maximus Monaheng Sefotho ${ }^{1}$ \\ ${ }^{1}$ Department of Educational Psychology, University of Johannesburg, South-Africa \\ ${ }^{2}$ Department of Educational Foundations, University of Nigeria, Nsukka, Nigeria \\ Correspondence: Maximus Monaheng Sefotho, Department of Educational Psychology, University of Johannesburg, \\ South-Africa.
}

Received: August 2, 2020

Accepted: September 11, $2020 \quad$ Online Published: September 18, 2020

doi:10.5430/ijhe.v9n6p136

URL: https://doi.org/10.5430/ijhe.v9n6p136

\begin{abstract}
Implementing differentiated instruction (DI) in inclusive classrooms presents many challenges that often limit the teachers' ability to use the strategy. Research tends to indicate that, though DI is a viable approach to meeting the le individual learner's needs in mixed ability classrooms; it is poorly implemented in regular schools. This study sought to investigate the perspectives of primary school teachers on the use of DI in an inclusive classroom in Enugu state, Nigeria. The study adopted a descriptive survey research design using a sample of 382 primary school teachers in the study area. Data were collected using a validated researcher-developed Teachers' Use of Differentiated Instruction Questionnaire (TUDIQ). Percentages, pie-charts, and bar charts were used in analyzing and presentation of data collected for the study. Results indicated that the extent to which teachers implement DI was low, and time constraint limits the use of DI. The results further revealed that teachers need more information on how to develop rubrics; students' directed assessments; how to manage large class while implementing DI; how to use differentiated instruction without watering down the curriculum contents; the need for changes in classroom structure to accommodate small groups; and the need for more training on DI and the provision of diverse learning aids in schools. The implication for teacher education is that DI has to form critical curriculum content for colleges of education and faculties of Education in the Universities.
\end{abstract}

Keywords: differentiated instruction, teachers, diverse learners, inclusive education

\section{Introduction}

Globally, there is a paradigm shift towards inclusive education. This is the education of all learners, including those with special needs in regular rather than in segregated schools. The inclusion of children with special needs in regular schools predisposes the classroom to more diverse learners (Blackman, 2017; Mngo \& Mngo, 2018; Saloviita, 2020). Moreover, the No Child Left Behind Act which was signed into law in 2002 necessitated the policy of providing "Education for All". The legislation ushered in the philosophy that the majority of students with special needs be moved out of segregated classrooms to regular classrooms where they can learn together with their peers. This brings more diverse learners to the classroom. Learners differ in their strengths, needs, learning preferences, backgrounds, interests, abilities and disabilities, gender, and educational experiences. Apart from these differences and peculiarities, children also learn differently with different learning styles. Some are auditory learners, some kinesthetic and others learn better visually. On the other hand, some learn better in formal setting and others in a more relaxed atmosphere (Ahuja, Ainscow, Bouya-Aka, Cruz, Eklindh \& Ferreira, 2005; Benneth, 2003; Brissett, 2019).

A neglect of these fundamental diversities as well as the use of a singular teaching approach threatens the classroom inclusiveness and may put a good number of learners with special needs at the risk of dropping out, lagging, losing motivation, getting bored, failing to learn and not maximizing their potential (Siam \& Al-Natour, 2016). Evidence shows that with the provision of effective teaching, about 40-50\% of learners with learning needs may attain good educational outcomes equivalent to their regular classroom peers (Mcleskey \& Nancy, 2011). To ensure that all learners in inclusive learning settings benefit maximally from instruction, classroom teachers have the responsibility of ensuring that all learners in the regular classroom, to the greatest possible extent, make progress in their learning 
irrespective of any form of individual difference (Heacox, 2012; Spencer-Waterman, 2014; Watts, Taffe, Broach, Marinak, McDonald Connor, \& Walker-Dalhouse, 2012).

The untrained staff has been viewed as one of the major constraints to inclusive education in Enugu state, Nigeria (Wolery et al., 1993). Many teachers feel that they are not well prepared and that they do not possess the appropriate and prerequisite skills needed to teach diverse learners in the classroom (Heacox, 2012; Suprayogi, Valcke \& Godwin, 2017). The presence of diverse learners with varying bits of intelligence, abilities and disabilities, interests and needs and with different learning styles has portrayed the need for teachers to rethink on relevant and research-based instructional strategies and practices that will enable them to meet the varying needs of the diverse learners (Heacox, 2012; Suprayogi, Valcke \& Godwin, 2017; Heckaman et al., 2009; Subban, 2006). This places an increased responsibility on the teacher who has to diversify instructional content, methods, materials, and assessment strategies through the use of differentiated instruction to accommodate all learners and help them maximize their potentials.

\subsection{Differentiated Instruction (DI)}

Differentiated instruction means matching students' approaches to learning with the most appropriate pedagogy, curriculum goals, and opportunities for displaying knowledge gained (Spencer-Waterman, 2014). Tucker, (2011) views differentiation as the practice of modifying and adapting instruction, materials, content, students' project, and product and assessment to meet the learning needs of individual students. DI means giving students multiple options for taking in information (Tomlinson \& Imbeau, 2010).

Differentiated instruction is an approach that enables teachers to plan strategically to meet the needs of every student. It is an educational theory that employs multiple teaching approaches in the same classroom to accommodate the variety of aptitudes, needs, personalities, and experiences of individual students (Mulder, 2014). Differentiated instruction is inquiry-based, interest-based, learner-oriented and activity-intensive (Chamberlin \& Power, 2010; Smit \& Humpert, 2012; Tomlison, 1999). Looking at a typical classroom as a collection of learners of different ability levels, readiness, interest, one can infer that teachers who do not differentiate instruction teach only a fraction of their students (Chamberlin \& Power, 2010; Koeze, 2007). Thus, implementing DI enables educators to meet the needs of individual students in their different skill levels in the same classroom (Smit \& Humpert, 2012; Tomlinson \& Imbeau, 2010). Furthermore, differentiation suggests that teachers can craft lessons in ways that tap into multiple student interests to promote heightened learner interest and test scores (Fitzgerald, 2016; Lauria, 2010)

To differentiate instruction, the teacher observes and understands the individual differences among students, and use the information to plan instruction (Koeze 2007; Landrum \& Mcduffie, 2010; Onyishi, 2017; Thakur, 2014; Walton, 2017). Differentiation, therefore, is an instructional approach that provides learners with multiple options, alternatives, and avenues to what they learn, how they can learn, and how they express what they have learned. Teachers are expected to teach all the pupils by providing differentiated instruction in content, process, product, and learning environment. DI provides teachers with the opportunity to accommodate different challenges and abilities in the classroom (Abdullah et al., 2014; Chamberlin \& Powers, 2010; Flaherty \& Hackler, 2010; Thakur, 2014). Studies (Garba, 2015; Kreitzer, 2016; Vaughn \& Linan, 2003) have shown that differentiated instruction has improved the learning achievement of students. Differentiated instruction engages students, stimulates their interest and provides gratifying experiences (Wiselby, 2014). This could be based on research finding that shows that children learn best using their preferred learning style and yet some teachers ignore this fact and they do not allow learners to learn using their preferred learning style (Smit \& Humpert, 2012; Benneth, 2003). Through the differentiating process, the teacher offers diverse ways in which learners can access the curriculum (Thakur, 2014; Walton, 2017).

However, the major challenges to differentiated instruction include those related to students, the school environment, the differentiated instruction, and teachers (Aldossari, 2018). Lunsford, (2017) showed that before DI can be fully implemented, teachers need professional development that defined what differentiated instruction is, how to implement it, and how to get to know their students better, as well as time to observe other teachers implementing differentiated instruction. Lunsford further suggested the need for supporting teachers to conquer the challenges of implementing DI and enhance teachers' indulgence in DI, especially in a mixed-ability classroom. DI is versatile and necessitates training, an optimistic approach to implement it, preparation time, and organizational support (Acosta-Tello \& Shepherd, 2014).

The demanding nature of DI can hinder the teacher from implementing the method in spite of the fact that it has widely been recognized to meet the learners' diverse learning needs (Martin, 2013). This tends to potentiate compounded problems for students and the education system (Lunsford, 2017). For instance, in a situation of non-implementation of DI, students' needs may not be met (Roe, 2010), Gifted students may not be challenged 
(Berman, Schultz \& Weber, 2012; Manning, Stanford \& Reeves, 2010; Schmitt \& Goebel, 2015; Seedorf, 2014); learners with special education needs may be left behind as some might need different learning strategies (Hornby, 2011) and regular students may fail to reach their full potential (King-Sears, 2008).

In the traditional regular schools, a good number of teachers take the children as if they are a homogenous group. They teach them the same curriculum content, using the same process and teaching method, and also expect them to express what they have learned in the same way and most cases using a paper-pencil test. They do not take cognizance of their varying interests, needs, abilities, disabilities, and learning styles. They take a "one-size-cap-fits-all" approach, which leaves too many students behind instead of moving them forward (Tomlinson, 2002). In the large group classes teachers who employ this teaching approach often teach to the middle and ignore the challenge of providing an enriched curriculum for those who are gifted and talented and also scaffolding curriculum for those who perform at a lower level (Tucker, 2011). Current research studies have shown differentiated instruction is a pedagogical approach which makes for modifications in the content, process, environment and assessment procedures so that every child can be accommodated in schools irrespective of their abilities, disabilities, interest and learning styles (Gentry, Sallie \& Sanders, 2013; Kovtiuh, 2017; Suban, 2006; Tomlinson, 2008). However, Munro (2012) pointed out that teachers can differentiate their teaching more effectively only when they: (1) understand how these students learn and think; (2) know a range of teaching options for differentiating their teaching; (3) can apply the differentiated teaching to topics in their classroom; (4) have the appropriate motivation orientation; and (5) can read the culture and climate in their school and classroom in terms of this differentiation.

Though developed countries are advancing in the implementation of DI, African countries are still below expectation in terms of implementation (Adetoro, 2014; Charema, 2010; Srivastava, de Boer \& Pijl, 2015). This could be due to some culturally based assumptions about the capabilities of persons with disabilities and lack of competence on the part of the teachers (Charema, 2010; Srivastava et al., 2015). Teaching and learning are persistently following the old teacher-centered pedagogies (Spratt \& Florián, 2013; Schweisfurth, 2011; Srivastava, et al., 2015) which rarely meet the need of learners with diverse learning needs (Mitchel, 2017). Nevertheless, from the theoretical point of view, learners learn best when they are exposed to learning contents in ways that speak to their individual levels of expertise/zone of proximal development, specific intelligences and learning needs (Gardner, 1983; Vygotsky, 1978).

\subsection{Theoretical Framework}

This study is anchored on Vygotsky's 1978 sociocultural theory of cognitive development, and Gardner's theory of multiple intelligences. Vygotsky strongly opined that children actively construct knowledge. Vygotsky stressed that social interaction and culture interplay and exert a significant role in learning. Vygotsky sees learning as a process and not a product. Vygotsky believes that learning is simulative and collaborative. Knowledge is constructed as the learner interacts, discusses and compares ideas with people in the environment such as teachers and skillful peers. This helps the child to progress in cognitive development. Vygotsky believes that there is a gap between what a child can learn independently and what the child can learn with the assistance of adults and or skilled peers (the more knowledgeable others). This he referred to as the Zone of proximal development (ZPD). He stressed that the low level of the ZPD is what a child can learn independently while the high level is what the child can learn with the support and assistance of adults or the more skilled peers. It is the responsibility of the teacher to scaffold by changing the level of support and guidance to move the child from where he is to a level, he /she can attain. The ZPD is attained through dialogue. This theory has implications for differentiated instruction. Social interaction which is the thrust of this theory has implications for student-teacher interaction as well as student-student interaction. It also supports collaborative learning which is pertinent in differentiated instruction.

On the other hand, Gardner (1983) established eight criteria for identifying the seven separate bits of intelligence, including verbal/linguistic, logical/mathematical, visual/spatial, bodily-kinesthetic, musical, interpersonal, intrapersonal, naturalistic, and existential, verbal or linguistic intelligence refers to an individual's ability to understand and manipulate words and languages. Further, the theory holds that intelligence encompasses the ability to create and solve problems, create products, and provide services that are valued within the context of diversity (Gardner, 1983). Differentiated instruction seeks to equip the students with skills for problem-solving and creating products that are desirable in the context of the content being learned.

The idea of differentiating instruction to accommodate the different ways that students learn involves a hefty dose of common sense, as well as study support in the theory and research of education (Fox \& Hoffman, 2011). It is an approach to teaching that advocates active planning for student differences in classrooms. Differentiated instruction is a flexible, equitable, and intelligent way to approach teaching and learning (Fox \& Hoffman, 2011). DI allows 
teachers to present varying learning activities and different content, as well as adopt varying modes of assessment to meet the needs of each child (Suprayogi, Valcke \& Godwin, 2017). Teachers need to modify and adapt their teaching content, approaches, environment, and assessment to meet the diverse learners in the classroom where they are and scaffold them to where they should be. DI encompasses such concepts as 'differentiated assessment', 'inclusion', 'student-centeredness' (Fox \& Hoffman, 2011) 'individualized instruction' (Suprayogi et al, 2017), 'adaptive instruction', 'personalized learning' (Waxman, Alford, \& Brown, 2013), 'response to intervention' (Fox \& Hoffman, 2011), and Universal Design of Learning (UDL) (Hall, Strangman, \& Meyer, 2014). Irrespective of the different labels DI seeks to cope with the diversity of students, adopt specific teaching strategies, appeal to variety in learning activities, monitor individual student needs and pursue optimal learning outcome (Fox \& Hoffman, 2011; Hall, Strangman, \& Meyer, 2014; Suprayogi, et al, 2017; Waxman, Alford, \& Brown, 2013).

\subsection{Empirical Studies on Differentiated Instruction}

Karadag and Yasar (2010) investigated the effects of differentiated instruction on students' attitudes towards Turkish courses. The study aimed to determine the effects of a differentiated instruction approach on students' attitudes in the Turkish course. The study was carried out through an action research approach and conducted with 45 fifth grade students in Turkey. Data of the study were collected through the Turkish Course Attitude Scale and semi-structured interviews. The qualitative data collected were analyzed through "NVivo 8" program, and the quantitative data were analyzed with the SPSS program. The results of the study revealed that the differentiated instruction approach influenced the students' attitudes toward the Turkish course positively.

Abdullah et al. (2014) explored the effect of differentiated learning method (DLM) on students' achievement in writing skills in Arabic as a foreign language in Malaysia using a sample of 100 students (47 males and 53 females). The pre-and post-tests comparison groups design was used to determine if there were significant differences between the experimental and control groups. The experimental group was taught using DLM, while the control group was taught using the teacher-cantered method (TCM). Descriptive statistics were used to determine the effect of DLM on students' achievement in writing skills. The statistical results demonstrated that there was a significant difference in the post-test between the experimental group $(\mathrm{M}=10.14, \mathrm{SD}=2.79)$ and the control group $(\mathrm{M}=8.20, \mathrm{SD}=2.38) ; \mathrm{t}(3.73), \mathrm{p}<$ $.05)$. The experimental group's achievement was generally more than the control group's which proves that the DLM is an effective approach in improving students' writing achievement in Arabic Language.

In 2015, Garba and Muhammad investigated the effectiveness of differentiated instruction on students' geometric achievement in Kebbi state senior secondary schools. The study adopted a pretest-posttest control group design. The population consists of 69,573 students. A random sampling technique was used in selecting the schools and the level of the students. A sample size of 96 participants was selected for the study which is following the Central Limit Theorem that regarded a minimum of 30 sample size viable for experimental research. The sample is made up of 55 male students and 41 female students. A geometric achievement test (GAT) was the instrument used in collecting data for the study. A Spearman-Brown equal length reliability coefficient of 0.76 was achieved using the split-half method. The data were analyzed using mean, standard deviation, and t-test all at $5 \%$ level of significance. The result showed that differentiated instruction is more effective in facilitating students' achievement in geometry than the lecture method.

King (2010) conducted a research associated with inclusive classroom teachers' implementation of differentiated instruction for diverse learners. The purpose of the research was to examine teachers' knowledge as well as their perception regarding the implementation of differentiated instruction. The study also explored factors that teachers perceive as barriers in implementing differentiated instruction in inclusive classrooms. The Teachers' Perception and Knowledge Regarding Differentiated Instruction (TPKRDI) instrument used to collect data from 220 regular education and special education teachers. The findings of the study indicated among others that there was a significant relationship between teachers' perception about, knowledge of differentiated instruction, and their practice of using it in inclusive classrooms. Time was also identified as a factor in the use of differentiated instruction.

Adlam (2015) investigated the knowledge possessed by Elementary teachers when implementing differentiated instruction in their classroom and frequency of use of differentiated strategies in different subject areas. 72 employees from the Greater Essex Country District School Board (GECDSB) participated in the study. Data were generated using qualitative and quantitative survey questions on the knowledge and use of differentiated instruction. Findings revealed that different teachers adopt different differentiation strategies - learning contracts, tiered assignments, independent projects, curriculum compacting, interest centers, learning centers, flexible grouping, and pre-assessment in different frequencies. 
In a mixed-method study, Siam and Al-Natour (2016) sought to investigate Teacher's Differentiated Instruction Practices and Implementation Challenges for Learning Disabilities. A questionnaire of 75 items measured differentiated practices in six domains (differentiation in content, process, resources, product, assessment, and differentiation in the learning environment). Results indicated that the mean of the scores for the six domains and the entire items are low. Challenges, to differentiated instruction, were identified, including weak administrative support, low parental support, lack of time, and shortages in learning resources.

Suprayogi, Valcke and Godwin (2017) in their study on Teachers and their implementation of differentiated instruction 2 in the classroom found that DI implementation of teachers is linked to a complex set of variables, including teachers' DI self-efficacy, teaching beliefs, teaching experience, professional development, teacher certification, and classroom size. The findings show that DI implementation is still below a critical benchmark. A study by Abu-Hamourand and Al-Hamouz (2013) found that the realization of "inclusion" in its full sense is still far away due to lack of training for professional teachers on the implementation of differentiated instruction for students with special needs who are placed in inclusive classrooms. A similar study by Lora, Nancy, and Jerita (2014) found that apart from lack of training, a major challenge to the implementation of differentiated instruction is that it takes time to apply, and there is need for the professional development of teachers so they can manage a class and apply effective strategies of differentiated instruction to cater for the needs of every learner within an inclusive environment.

Dixon, Yssel, McConnell, and Hardin (2014) carried out a study aimed at finding out the role professional training plays in the implementation of differentiated instruction and the effectiveness and self-efficacy of teachers. The study investigated the self-efficacy and the effectiveness of teachers using the variables: educational locations, basic-level schools, teachers' experiences, and the number of professional development training teachers had undergone. The results showed a positive and proportional relationship between teachers' qualifications and their effectiveness in implementing differentiated instruction.

There was a study by Roiha (2012) entitled "Teachers views on differentiation in Content and Language Integrated Learning (CLIL) in terms of vision, practices, and challenges." The study examined the diversity of content and merging of languages in CLIL in Finland to figure out ways of supporting individual students with special needs in public classrooms in teachers' perceptions of differentiated instruction. Results showed that problems associated with differentiated instruction had to do with time, materials, and class environment. In another study, "teachers and differentiated instruction: exploring differentiation practices to address student diversity" Pozas, Letzel, and Schneider, (2019) explored German (as native language) and Mathematics teachers' use of DI practices in Germany. Results from a mixed analysis of covariance indicated that teachers implemented DI practices only on an occasional basis.

In Nigeria, the extent to which teachers have implemented DI in the regular classrooms, and the difficulties they encounter have not been investigated. Also, there is a gap in the literature on empirical studies that address whether the difficulties professional teachers may encounter in implementing differentiated instruction are related to teachers teaching experience and gender. Additionally, there is a lack of empirical evidence on the areas in which the teachers need more training in other to implement differentiated instruction and the implication to teacher education. Information along these lines may help teacher education institutions and professional teachers to understand the areas they need to lay more emphasis during teacher training. The government and school administrators will get to know more about the difficulties teachers encounter in implementing differentiated instruction in the classroom and also suggestions on how these difficulties can be surmounted so that every learner's interests, needs, and abilities could be met. These may invariably make the learners learn more effectively. Based on these, the present study sought to fill this existing gap, especially as it pertains to Basic school teachers in Enugu state.

\subsection{The Current Study}

To fill the glaring gaps in the literature identified in the preceding discourse, the current study sought to investigate teachers' perspectives about DI in inclusive primary schools in Enugu State, Nigeria. Specifically, investigated teachers' use of DI; difficulties encountered by teachers in implementing DI; areas thee teachers need information for DI implementation and the professional development need for DI. According to Tomlinson (2001), teachers who differentiate provide multiple learning options, Use instructional approach that allows the student to use their senses. Evidence-based studies show that teachers need to provide appropriate challenges for learners who have learning difficulties and those who are gifted (Ismajli \& Imami-Morina, 2018). Aditionally, teachers who differentiate allow pupils to work cooperatively with peers, individualize teaching, use assessment to inform instruction and give the students multiple options to express what they have learnt (Bryant, Maarouf, Burcham \& Greer, 2016). 
Other studies in other countries identified that teachers' challenges with DI implementation include time constraint, inability to cover contents at the stipulated time, class space is too compact to arrange in order to create learning centers and work stations, rigidity in school time table, how to link formative assessment to instruction and lack of teaching materials (Aldossari, 2018; Bryant, Maarouf, Burcham \& Greer, 2016; Ismajli \& Imami-Morina, 2018). Hence, it has been suggested that teachers need more information development of rubrics, conducting students directed assessments, using projects to solve problem in the classroom, management of large class while implementing DI, how to differentiate instructions without watering down the curriculum (Aldossari, 2018; Lunsford, 2017).

Teachers' perceptions of the need for professional development suggest changes in classroom structure and environment to accommodate small groups during teach/learning. Consistent training on DI is needful, monitoring teachers' use of DI, provision of diverse learning aids. Teachers also need professional development that defined what differentiated instruction is, how to implement it, and how to get to know their students better, as well as time to observe other teachers implementing differentiated instruction (Lunsford, 2017). This study measured teachers' perspectives in these dimensions as captured in the research questions.

\subsection{Research Questions}

1. To what extent do teachers adopt differentiated instruction in inclusive classrooms?

2. What are the difficulties encountered by teachers in implementing differentiated instruction in the classrooms?

3. What are the areas teachers need more information for them to be able to implement differentiated instruction in schools?

\section{Method}

\subsection{Research Design}

The study adopted a descriptive survey research design. This design enabled the researcher to collect data systematically, on the features and facts about teachers and their use of differentiated instruction in their various classes.

\subsection{Population}

The population for the study comprised all the 1,626 primary school teachers who were trained on differentiated instruction in Enugu state. They include 475 teachers from Enugu East, 546 from Enugu West, and 605 from Enugu North. There were 288 males and 1338 females of the primary school teachers who were trained on differentiated instruction in Enugu state. The teachers were selected based on their working experience and training they have undergone. The new teachers were those who have 0-5 years of working experience while the old teachers were those who had 6-20 years of working experience.

\subsection{Sample and Sampling Technique}

The sample was 382 teachers consisting of 116 males and 266 females. This sample represents $40 \%$ males and $20 \%$ females. They were randomly sampled from the population based on the suggestions that, in selecting a sample size no fixed percentage of the sample is ideal but $40 \%$ of a population of many hundreds will do, if few thousands, a sample size of $10 \%$ or more will do and if several thousand, a $5 \%$ or less sample will be adequate (Baker, Brick, Bates, Battaglia, Couper, Dever,... \& Tourangeau, 2013).

\subsection{Instrument for Data Collection}

Quantitative data were collected using a researcher constructed questionnaire titled "Teachers' Use of Differentiated Instruction Questionnaire (TUDIQ)". The TUDIQ comprised of two sections. Section 'A' elicited information based on the demographic information of the respondents such as gender, years of working experience, and teaching qualification. Section B comprised of 23 items which are divided into four clusters. Cluster A dealt with the extent teachers implement differentiated instruction in regular schools, section B dealt with the areas teachers experience difficulties implementing differentiated instruction, section $\mathrm{C}$ dealt with areas teachers need more information for them to be able to implement differentiated instruction in schools, Section D dealt with the perception of teachers on what could be done for them to improve on their use of differentiated instruction. The instrument is structured on a four-point scale of Strongly Agree, Agree, Disagree, and Strongly Disagree. The TUDIQ was validated by presenting the initial draft to three experts who were specifically requested to assess the relevance of the items in collecting the required data. The observations and suggestions of these experts were incorporated in the final production of the 
instrument. To ascertain the reliability of TUDIQ, it was trial tested in a survey sample of 67 teachers from outside the study. The reliability coefficient was derived using the Cronbach Alpha statistics, which yielded a reliability coefficient of 0.88 , which showed that the instrument is reliable.

\subsection{Data Collection and Analysis}

The researchers with the help of two research assistants administered the questionnaires directly to the participants and collected them back on the spot. The study employed percentages, bar and pie charts in the analysis and presentation of data for the study.

\section{Results}

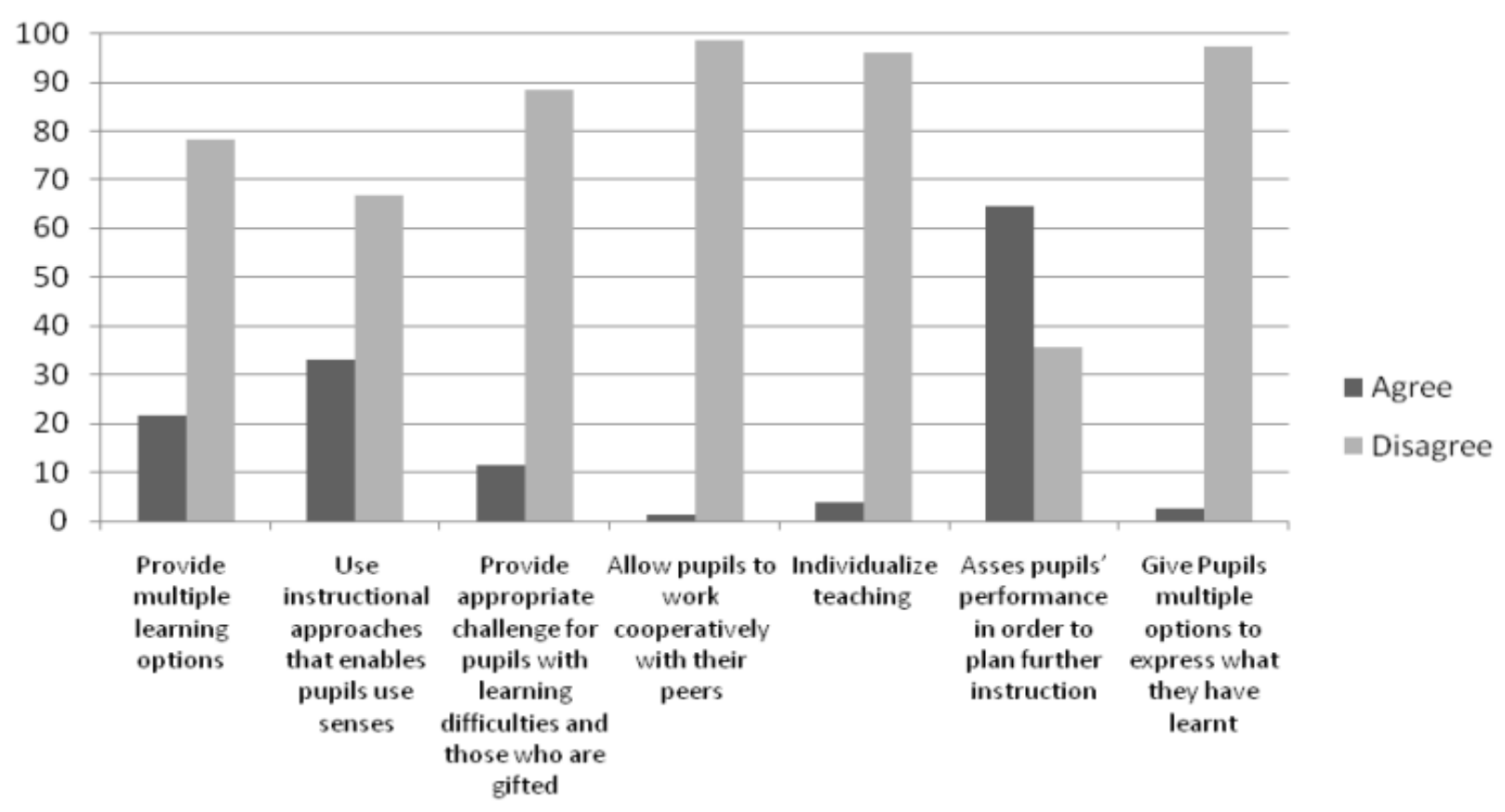

Figure 1. Extent of teachers' implementation of DI in regular schools

The data on the extent of teachers' use of differentiated instruction, the four responses in the questionnaire are divided into two. Strongly agree or agree it implies that the respondent implements that differentiated strategy while disagreeing and strongly disagree shows that the respondent does not do what is stated in that item. The items of the questionnaire are constructed using normal language which each represents a differentiated instructional strategy. For instance, provide multiple learning options represents tiered assignment; Use an instructional approach that enables pupils to use different senses represents - varied instructional materials; Providing appropriate challenge for pupils with learning difficulties and those who are gifted represents interest centers and curriculum compacting. Allowing pupils to work cooperatively with their peers represents grouping/working in small groups; individualized teaching represents teaching up; Assessing the pupils' performance to plan further instruction represents Pre-assessment and finally, giving pupils multiple options to express what they have learned represents the use of choice boards/ varying questions. Of all the features of differentiation that are highlighted, the highest practiced among the teachers is assessing students' performance to plan further instruction, which represents pre-assessment. $246(64.4 \%)$ of the teacher indicated that they assess pupils' performances to plan instruction while $136(35.6 \%)$ of the teachers submitted that they do not assess students' performance before planning further instruction.

Teachers' responses to item 2 show that only about 127 (33\%) use instructional approaches that enable students to take in information through different senses (varied instructional materials). The other 255 (67\%) of the teachers do not use such an instructional approach that present varied instructional materials. $83(21 \%)$ of the teachers agreed that they provide multiple learning options that appeal to the different learning abilities, interests, and learning styles of the pupils (learning centers/ interest centers/curriculum compacting). The whole other 299 (79\%) of the teachers do not provide multiple learning options for their pupils in the classroom. 
Only $44(11.5 \%)$ of the 382 teachers indicated that they provide the appropriate level of challenge for those with learning difficulty, those at the middle and for those who are gifted in the class (compacting), while the other 338 $(88.5 \%)$ do not implement that aspect of differentiation. $5(1.3 \%)$ of the teachers allow pupils to work cooperatively with their peers based on their areas of interest and readiness (flexible grouping), 377 (98.7\%) of the teachers do not encourage cooperative work based on interest areas.

On the other hand, 15 (3.9\%) of the teachers practice individualized teaching based on the needs and interests of the pupils. $10(2.6 \%)$ of the teachers give multiple options on how to express what they have learned using Choice boards and tiered assignments.

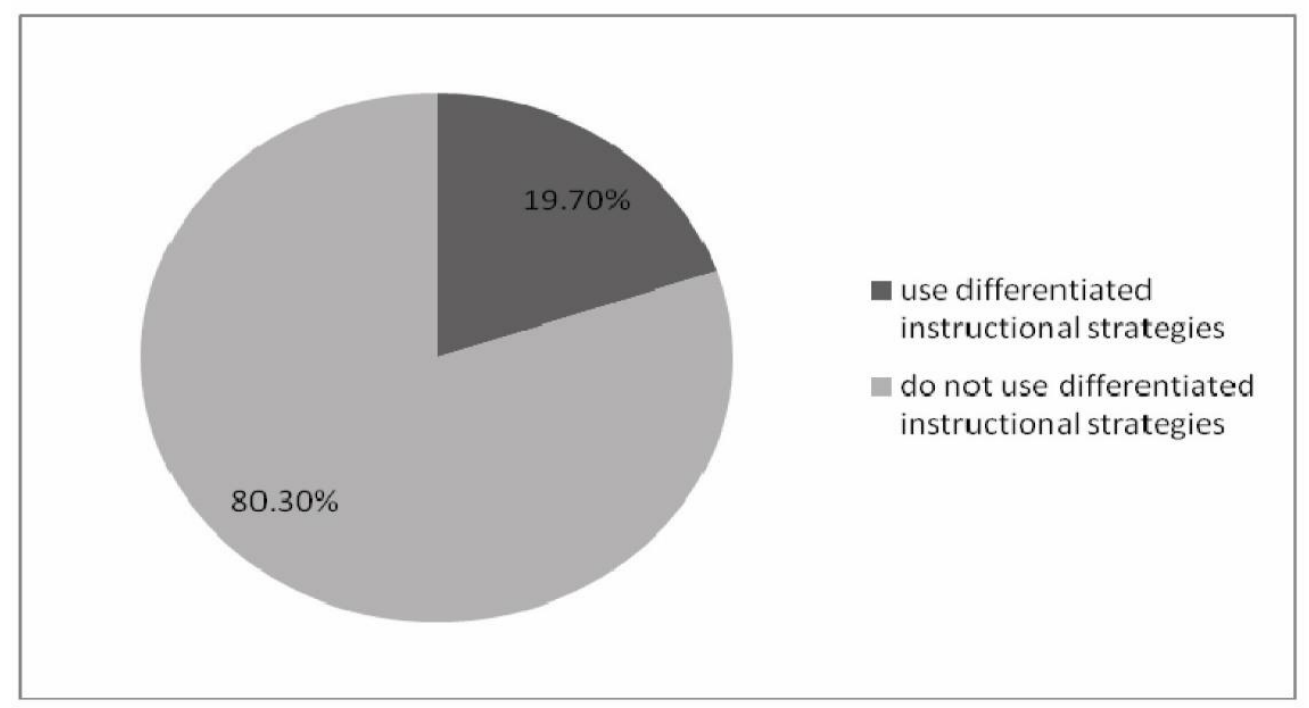

Figure 2. The overall percentage of teachers who use DI strategies

On average, the pie chart shows that only $19.7 \%$ of all the primary school teachers in the state use differentiated instructional strategies.

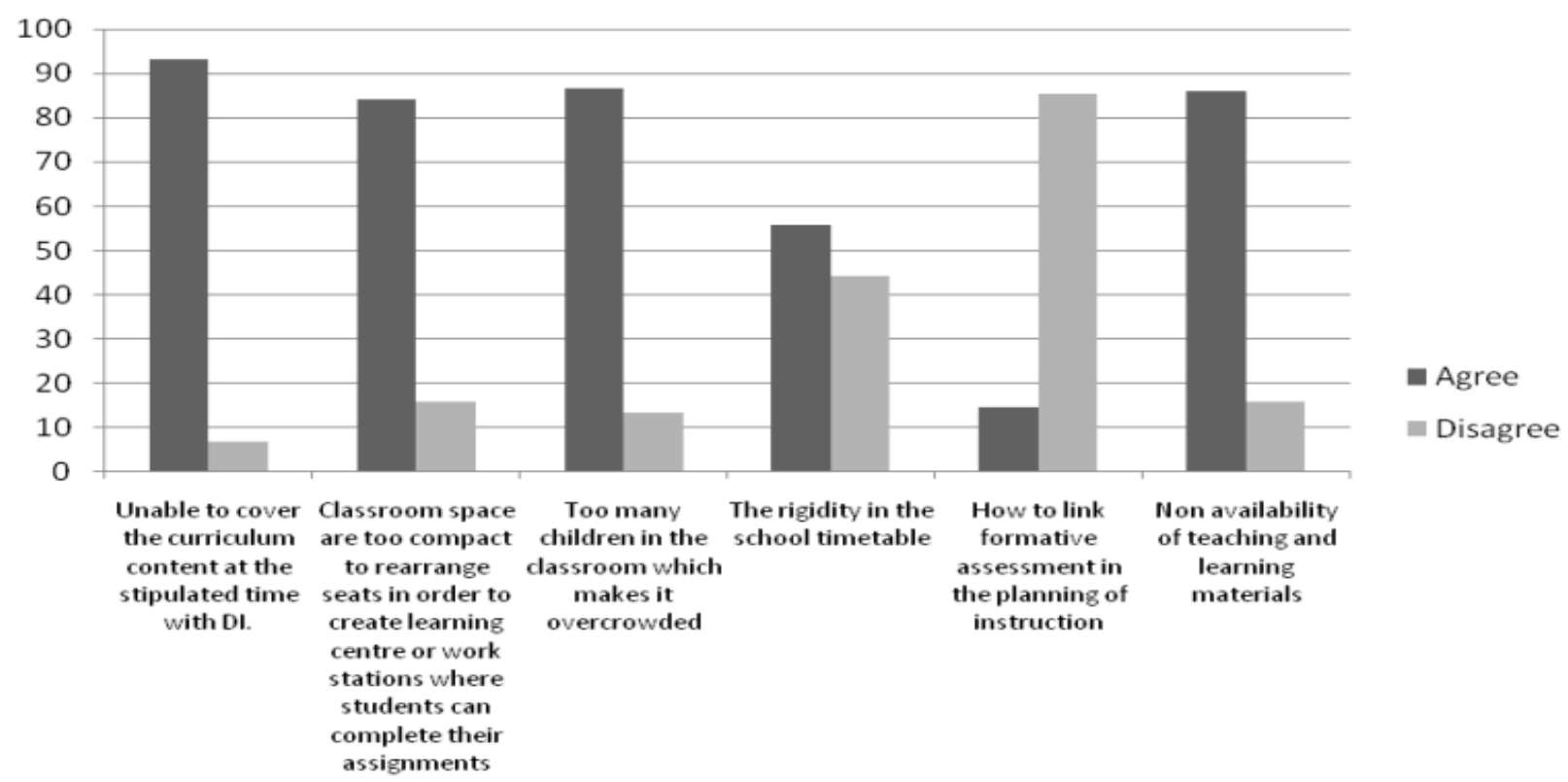

Figure 3. Difficulties teachers encounter in implementing differentiated instruction in schools

$356(93 \%)$ of the participants indicated that difficulties they encountered implementing differentiated instruction include being unable to cover the curriculum content at the stipulated time. $7 \%$ of the participants that do not agree with this item. The further interview showed that those few ones who do not encounter the problem of time are those who tend to give a lot of assignments which enables the pupils to do much work at home thereby reducing the class Published by Sciedu Press 
workload. $331(86.6 \%)$ of the teachers agreed that having too many children in one classroom is another major difficulty they encounter. $329(86.1 \%)$ of the teachers agreed that non-availability of teaching and learning materials is one of the major difficulties they encounter while $321(84 \%)$ of the teachers agreed that they are having a problem with Classroom space to rearrange seats to create learning center or work stations where students can complete their assignments. $5.7 \%$ and $14.4 \%$ of the teachers respectively agreed that rigidity in the school timetable and linking formative assessment in the planning of instruction are also major problems.

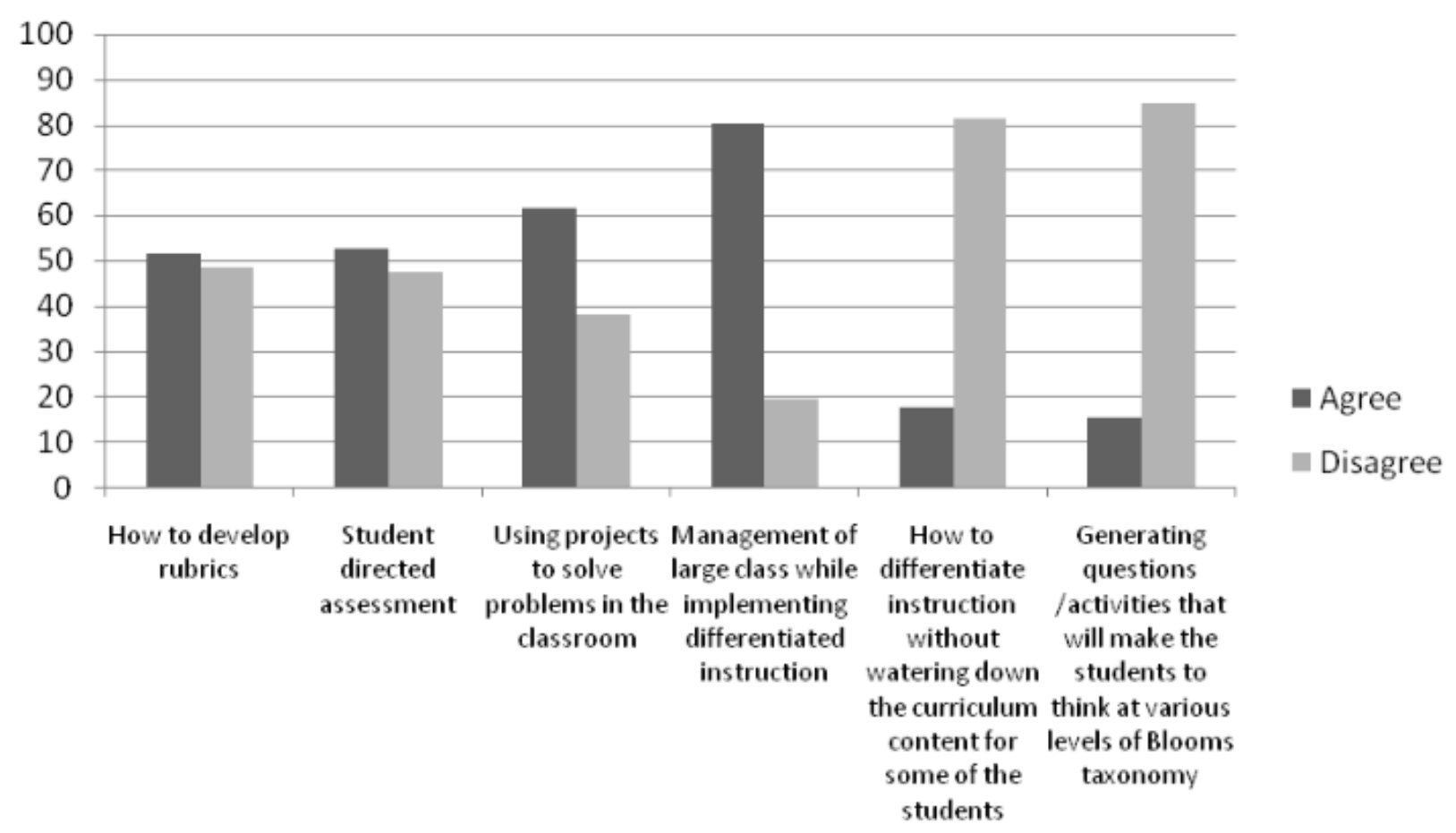

Figure 4. Areas that teachers need more information for them to able to implementing differentiated instruction in schools

The above chart indicates that $51 \%$ of the teachers agreed that they need more information on how to develop rubrics, $53 \%$ need more information on students' directed assessment, while $62 \%$ need information on how to manage large class while implementing differentiated instruction. Only 18\% needs more information on how to differentiate instruction without watering down the curriculum content, $15 \%$ indicated that they need more information on generating questions that will make the students think at various levels of Bloom's taxonomy. 


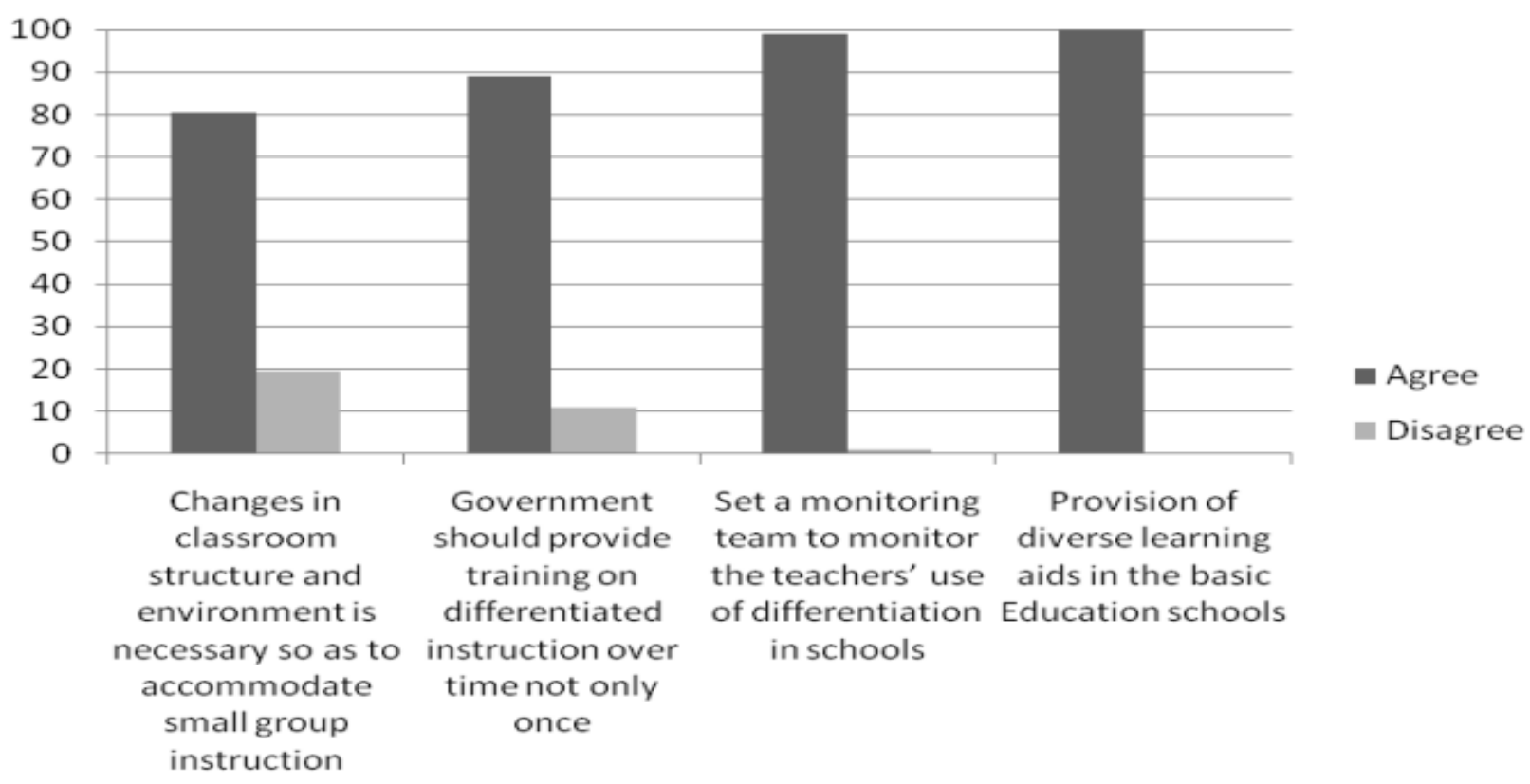

Figure 5. Perception of teachers on professional development that will be required for the teachers to improve on the use of differentiated instruction

Data in the above distribution shows that the majority of the teachers $-80 \%$ agree that they need changes in classroom structure and the environment to accommodate small group instruction in implementing DI. 89\% submitted that the government should provide more training on DI over time before they can effectively implement it. 99\% of the teachers also believe in the government should set up a special monitoring team to supervise the teachers' use of differentiation. All the participants agreed that the provision of diverse learning aids in the Basic Education schools is paramount.

\section{Discussion of Findings}

The finding of the study revealed that the majority of teachers who participated in the study use differentiated instruction to a low extent. The only differentiated instruction strategy that is used to a high extent is the use of pre-assessment. This could be that the strategy does not need much preparation to implement. Practicing teachers already have the different skills required for the test of what is called a test of entry behaviors. The extent of use of other instructional strategies such as varied instructional materials, curriculum compacting, learning centers, flexible grouping, tiered assignments, and individualized teaching are very low among the participant. Generally, only about $20 \%$ of the participants adopt differentiated instruction strategies. This indicates that the extent of teachers' use of differentiated instruction in Enugu state Nigeria is still low.

In the area of difficulties encountered by the teachers in implementing differentiated instruction, most of the teachers indicated that time is their constraint to the use of differentiated instructional strategies. They indicated that when they use differentiated instruction, they find it difficult to cover the curriculum content in the stipulated time. However, when the researchers interacted with the few participants that did not agree to this difficulty, it was gathered that such teachers; utilize homework assignments to cover the scheme. The study also found out other difficulties encountered by teachers in using of DI to include too many children in one classroom; non-availability of teaching and learning materials; Classroom space to rearrange seats to create learning center or work stations where students can complete their assignments; rigidity in the school timetable; and linking formative assessment in the planning of instruction are also major problems. This result concurs with that of King, (2010) which indicates that time was a factor in teachers' implementation of differentiated instruction. Hollowell, (2016) observed that it is almost impossible for teachers to differentiate instruction in a classroom of over 20 learners. This also affirms that too many children in one class and classroom space were among the difficulties teachers in the area of this study encounter in implementing differentiated instruction. In the area of study, a standard regular classroom consists of $35-40$ pupils and this could mitigate the teachers' use of differentiated instruction.

The results of this study show that on the average, the teachers agreed that they need more information on how to develop rubrics; need more information on students' directed assessment; need information on how to manage large 
classes while implementing differentiated instruction. They also submitted that they need more information on how to differentiate instruction without watering down the curriculum content; and a few (about 15\%) indicated that they need more information on generating questions that will make the students think at various levels of Bloom's taxonomy. The result is consistent with Munro, (2012) which pointed out that teachers can differentiate their teaching more effectively only when they: (1) understand how these students learn and think; (2) know a range of teaching options for differentiating their teaching; (3) can apply the differentiated teaching to topics in their classroom; (4) have the appropriate motivation orientation; and (5) can read the culture and climate in their school and classroom in terms of this differentiation. On the other hand, Aldossari (2018) found that some teacher's belief that differentiated instruction is an absurdity leading to chaos

For the teachers to indicate that they need information in those areas for them to be able to carry out effective differentiation, it also connotes the importance of pedagogical and content knowledge in teaching, learning, and differentiation (Tomlinson \& Allan, 2000; Agwagah, 2013). According to Wolery et al. (1993) the major constraints to inclusive education is the untrained staff. Frunzăa, and Petreb (2015) found that curricular elements related to teachers' professional philosophy, the elements of the pedagogical training level, and interactional nature elements were the major obstacles to teachers' implementation of DI. So, when the teachers indicate that they need some information for them to be able to differentiate learning effectively, one would not be surprised. Though these teachers have been once trained, they still need training in differentiated instruction to increase their efficiency in differentiation. Prior study has revealed a disconnection between teachers' understanding of DI and their actual DI implementation, showing a lower rate of DI implementation compared to the understanding of DI (Whipple, 2012). This may suggest that even when the teachers are well informed about DI, they still need motivation and the confidence to implement the teaching method. Thus, studies reported other barriers to DI implementation may include being unfamiliar with available tools, the necessary preparation time, and a lack of resources (Rodriguez, 2012). Further, the time-consuming nature of DI and its difficulty to implement without assistance from colleagues limit teachers' disposition towards implementation (Smit \& Humpert, 2012).

Results in the area of teachers' perception of the professional development required for them to improve in the use of differentiated instruction identified the following. They need changes in classroom structure and the environment to accommodate small group instruction in implementing DI; Government should provide more training on DI over time before they can effectively implement it; Government should set up a special monitoring team to supervise the teachers' use of differentiation; Provision of diverse learning aids in the Basic Education schools. These findings affirm the findings of Aldossari (2018) who found that failure to prepare the potential teachers in higher education before service in a way that suits the requirements of differentiated instruction is a major challenge for DI in schools. Aldosari further found that poor knowledge and awareness of teachers about DI strategy and activities are an additional challenge to the use of DI. Apart from the teachers' awareness, adoption of DI as indicated by researchers prioritize the role of teacher variables such as teacher self-efficacy teaching beliefs, and other variables such as teaching experience, teacher certification, and classroom characteristics (Dixon, Yssel, McConnell \& Hardin, 2014; Wan, 2015).

\section{Implications for Teacher Education}

For teachers to be able to effectively differentiate learning, they need information in some areas like, how to develop rubrics; students' directed assessment; how to manage large class while implementing differentiated instruction, how to differentiate instruction without watering down the curriculum content and generating questions that will make the students think at various levels of Bloom's taxonomy. The Teacher-education curriculum should aim at developing potential teachers' expertise in these areas to improve their differentiated instruction skills. The findings of the present study also suggest that differentiated curriculum should be developed and fully implemented in teachers' education and all higher education institutions in general for effective teaching and learning.

It is also recommended that differentiation be built into the teacher education curriculum, so that prospective teacher in every teacher training institutions will undergo full courses in differentiation that will equip them with necessary skills for differentiation before going into the field. On the part of those teachers who are already in the field, in-service training in forms of workshops should be organized repeatedly to enable them to internalize the skills and strategies in differentiation.

Effective implementation of differentiated instruction also need the following efforts by the Government: changes in classroom structure and the environment to accommodate small group instruction in implementing DI; Government should provide more training on DI over time before they can effectively implement it; Government should set up a special monitoring team to supervise the teachers' use of differentiation; Provision of diverse learning aids in the Basic Education schools. 


\section{Conclusion}

Based on the findings of the study, the following conclusions are made: Differentiation has been identified as the most effective approach to teaching in an inclusive classroom setting, but teachers in Enugu state of Nigeria who teach in classrooms with inclusive characteristics seldom implement differentiated instruction strategies in teaching their pupils. The failure to differentiate by the teachers is attributed to the following factors: constraint of time, lack of diverse learning facilities, high-class population, poor knowledge and skills of the teachers, Classroom space to rearrange seats to create learning center or work stations where students can complete their assignments; and rigidity in the school timetable.

\section{References}

Abdullah, N., Roslan, S., Abdullah, M. C., \& HajiMaming P. (2014). The effect of differentiated learning method on students achievement in writing skills in learning Arabic as a foreign language. International Journal of Research in Education Methodology, 6(2), 889-895. https://doi.org/10.24297/ijrem.v6i2.3884

Abu-Hamour, B., \& Al-Hamouz, H. (2013). Special Education in Jordan, European Journal of Special Needs Education. International Education Studies, 6(12).

Acosta-Tello, E., \& Shepherd, C. (2014). Equal access for all learners: Differentiation simplified. Journal of Research in Innovative Teaching, 7(1), 51-57.

Adlam, E. (2016). Differentiated Instruction in the Elementary School: Investigating the knowledge elementary teachers possess when implementing differentiated instruction in their classrooms. Retrieved from web4.uwindsor.ca/units/researchEthicsBoard...

Agwagah, U. N. V. (2013). Improving the teaching of mathematics for attainment of seven Point Agenda: Implication for Gender disparity. ABACUS. The journal of the mathematical Association of Nigeria, 38 (1), 111-121.

Ahuja, A., Ainscow, M., Bouya-Aka, A., Cruz, M., Eklindh, K., \& Ferreira, W. (2005). Guidelines for inclusion: Ensuring access to education for all. Paris: UNESCO. Retrieved June, 15(2015), 401-416.

Aldossari, A. T. (2018). The Challenges of Using the Differentiated Instruction Strategy: A Case Study in the General Education Stages in Saudi Arabia. International Education Studies, 11(4), 74-83. https://doi.org/10.5539/ies.v11n4p74

Aldossari, A. T. (2018). The Challenges of Using the Differentiated Instruction Strategy: A Case Study in the General Education Stages in Saudi Arabia. International Education Studies, 11(4), 74-83. https://doi.org/10.5539/ies.v11n4p74

Anderson, K. M. (2007). Differentiating instruction to include all learners. Preventing School Failure, 31(3), 49-54. https://doi.org/10.3200/PSFL.51.3.49-54

Bada, S. O., \& Olusegun, S. (2015). Constructivism learning theory: A paradigm for teaching and learning. Journal of Research \& Method in Education, 5(6), 66-70.

Baker, R., Brick, J. M., Bates, N. A., Battaglia, M., Couper, M. P., Dever, J. A., ... \& Tourangeau, R. (2013). Summary report of the AAPOR task force on non-probability sampling. Journal of survey statistics and methodology, 1(2), 90-143. https://doi.org/10.1093/jssam/smt008

Benneth, C. I. (2003). Comprehensive multicultural education: Theory and practice (5 ${ }^{\text {th }}$ Ed.) Pearson Education Inc. Boston USA.

Berman, K., Schultz, R., \& Weber, C. (2012). A lack of awareness and emphasis in preservice teacher training: Preconceived beliefs about the gifted and talented. Gifted Child Today, 35(1), 18-26. https://doi.org/10.177/1076217511428307

Blackman, S. (2017). From charity education towards inclusion. Caribbean Discourse in Inclusive Education: Historical and Contemporary Issues, 1 .

Brighton, C. M (2002). Straddling the fence: Implementing best practice in an age of accountability. Gifted Child Today, 25 (3), 30 -33. https://doi.org/10.4219/gct-2002-67

Brissett, N. O. (2019). Evolution of Educational Inclusion Policy Discourse in Jamaica: From Colonialism to Globalization. In Achieving Inclusive Education in the Caribbean and Beyond (pp. 17-33). Springer, Cham. https://doi.org/10.1007/978-3-030-15769-2_2 
Bryant, C. L., Maarouf, S., Burcham, J., \& Greer, D. (2016). The examination of a teacher candidate assessment rubric: A confirmatory factor analysis. Teaching and Teacher Education, 57, 79-96. http://dx.doi.org/10.1016/j.tate.2016.03.012

Cha, H. J., \& Ahn, M. L. (2014). Development of design guidelines for tools to promote differentiated instruction in classroom teaching. Asia Pacific Education Review, 15(4), 511-523. https://doi.org/10.1007/s12564-014-9337-6

Chamberlin, M., \& Power, R. (2010). The promise of differentiated instruction for enhancing the mathematical understandings of college students. Teaching mathematic and its application, 29(3), 113-139. https://doi.org/10.1093/teamat/hrq006

Corley, M. A. (2005). Differentiated instruction: Adjusting to the needs of all learners. Focus on Basics, 7, 13-16.

Danzi, J., Reul, K., \& Smith, R. (2008). Improving student motivation in mixed ability classrooms using differentiated instruction. Retrieved from ERIC database. (ED500838)

Deiner, P. L. (1993). Resources for educating children with diverse abilities: birth through eight. ( $3^{\text {rd }}$ Ed.) Delmar thomson learning Canada

Dixon, F. A., Yssel, N., McConnell, J. M., \& Hardin, T. (2014). Differentiated instruction, professional development, and teacher efficacy. Journal for the Education of the Gifted, 37(2), 111-127. https://doi.org/10.1177/0162353214529042

Dixon, F. A., Yssel, N., McConnell, J., \& Hardin, T. (2014). Differentiated Instruction Professional Development and Teacher Efficacy. Journal of the Education of Gifted, 37(2), 11-127. https://doi.org/10.1177/0162353214529042

Flaherty, S., \& Hackler, R. (2010). Exploring the Effects of Differentiated Instruction and Cooperative Learning on the Intrinsic Motivational Behaviors of Elementary Reading Students. Online Submission.

Fox, J., \& Hoffman, W. (2011). The Differentiated Instruction Book of Lists. San Francisco: Jossey-Bass.

Garba, A. A., \& Muhammad, S. A. (2015). The effectiveness of differentiated instruction on students' geometric achievement in Kebbi state senior secondary schools, Nigeria. International Journal of Scientific \& Engineering Research, 6(1). ISSN 2229-5518. Retrieved from IJSER @ 2015 http://www.ijser.org .

Garba, A. A., \& Muhammad, S. A. (2015). The effectiveness of differentiated instruction on students' geometric achievement in Kebbi state senior secondary schools, Nigeria. International Journal of Scientific \& Engineering Research, 6(1). Available at IJSER @ 2015 http://www.ijser.org. Accessed 23 May 2017.

Gentry, R., Sallie, A. P., \& Sanders, C. A. (2013). Differentiated Instructional Strategies to Accommodate Students with Varying Needs and Learning Styles. Online Submission.

Goodnough, K. (2010). Investigating pre-service science teachers' developing professional knowledge through the lens of differentiated instruction. Research in Science Education, 40(2), 239-265. https://doi.org/10.1007/s11165-009-9120-6

Hall, T., Strangman, N., \& Meyer, A. (2014). Differentiated instruction and implication for UDL implementation. Effective classroom practices report. National center on accessing the 710 general curriculum. Retrieved 1 February 2015 from http://aim.cast.org/sites/aim.cast.org/files/DI_UDL_10.6.14_0.docx.

Hallahan, D. P, \& Kauffman J. M. (2003). Exceptional learners (9 ${ }^{\text {th }}$. Ed.) Boston: Allyn \& Bacon.

Hardman, M. L., \& Dawson, S. (2008). The impact of federal public policy on curriculum and instruction for students with disabilities in the general education classroom. Preventing School Failure, 52(2), 5-11. https://doi.org/10.3200/PSFL.52.2.5-11

Heacox, D. (2012). Differentiating instruction in the regular classroom: How to reach and teach all learners. Golden Valley, MN: Free Spirit Publishing.

Heckaman, K., Thompson, S., Hull, K., \& Ernest, J. (2009). Preparing teacher candidates to use evidence-based practices to impact student learning. Southeastern Teacher Education Journal, 2(3), 5-17.

Ismajli, H., \& Imami-Morina, I. (2018). Differentiated Instruction: Understanding and Applying Interactive Strategies to Meet the Needs of All the Students. International Journal of Instruction, 11(3), 207-218. https://doi.org/10.12973/iji.2018.11315a

Johnsen, S. (2003). Adapting instruction to heterogeneous groups. Gifted Child Today, 26(3), 5-6. https://doi.org/10.1177/107621750302600302 
Koeze, P. A. (2007). Differentiated Instruction: the effect on student achievement in an elementary school. Master's Theses and Doctoral Dissertations. Paper 31. http://commons.emich.edu/theses.

Kovtiuh, S. (2017). Differentiated Instruction: Accommodating the Needs of All Learners.

Kreitzer, K. E. (2016). Differentiation For All Learners: Applying Theory and Practice So All Children Reach Their Potential.

Landrum, T. J., \& Mcduffie, K. A. (2010). Learning styles in the age of differentiated instruction. Exceptionality, 18 (1): 6-17. https://doi.org/10.1080/09362830903462441

Lauria, J. (2010). Differentiation through learning-style responsive strategies. Kappa Delta Pi Record, 47(1), 24-29. https://doi.org/10.1080/00228958.2010.10516556

Lora, R., Nancy, M., \& Jerita W. (2014). Perceptions about Implementation of Differentiated Instruction. Walden University.

Lunsford, K. J. (2017). Challenges to implementing differentiated instruction in middle school classrooms with mixed skill levels. https://scholarworks.waldenu.edu/dissertations

Manning, S., Stanford, B., \& Reeves, S. (2010). Valuing the advanced learner: Differentiating up. Cleaning House: A Journal of Educational Strategies, Issues and Ideas, 83(4), 145-149. https://doi.org/10.1080/00098651003774851

Martin, P. (2013). Role-playing in an inclusive classroom: Using realistic simulation to explore differentiated instruction. Issues in Teacher Education, 22(2), 93-106.

Mngo, Z. Y., \& Mngo, A. Y. (2018). Teachers' perceptions of inclusion in a pilot inclusive education program: Implications for instructional leadership. Education Research International, 2018. https://doi.org/10.1155/2018/3524879

Nandi, P. L., Chan, C. P. K., Chan, P, \& Chan, L.P. K. (2000). Undergraduate medical education: comparison of problem based learning and conventional teachings. Hong Kong Medical Journal, 6 (3), 301-306.

Njagi, M. W. (2014). Teachers' perspective towards differentiated instruction approach in teaching and learning mathematics in Kenya. International Journal of Humanities and Social Science, 4(13), 236-241.

Nunley, K. F. (2006). Differentiating in the high school, Thousand Oaks, CA: Corwin Press.

Osuafor, A. M., \& Okigbo, E.C. (2013). Effect of differentiated instruction on the academic achievement of Nigerian secondary school biology students. Educational Research, 4(7), 555-5161. https://doi.org/10.4314/afrrev.v7i3.12

Pozas, M., Letzel, V., \& Schneider, C. (2019). Teachers and differentiated instruction: exploring differentiation practices to address student diversity. Journal of Research in Special Educational Needs. https://doi.org/ $10.1111 / 1471-3802.12481$

Rodriguez, A. (2012). An analysis of elementary school teachers' knowledge and use of differentiated instruction. https://digitalcommons.olivet.edu/edd_diss/39

Roe, M. (2010). The ways teachers do the things they do: Differentiation in middle level literacy classes. Middle Grades Research Journal, 5(3), 139-152.

Roiha, A. S. (2014). Teachers' Views on Differentiation in Content and Language Integrated Learning (CLIL): Perceptions, Practices and Challenges. Language and Education, 28(1), 1-18. https://doi.org/10.1080/09500782.2012.748061

Saloviita, T. (2020). Attitudes of teachers towards inclusive education in Finland. Scandinavian Journal of Educational Research, 64(2), 270-282. http://dx.doi.org /10.1080/00313831.2018.1541819

Santrock, J. W. (2005). Children (8 ${ }^{\text {th }}$ ed.) Boston: Mc Graw-Hill.

Scheniquah King. (2010). Factors associated with inclusive classroom teachers' implementation of differentiated instruction for diverse learners. ETD Collection for Tennessee State University. Paper AAI3433402. http://digitalscholarship.tnstate.edu/dissertations/AAI3433402

Schmitt, C., \& Goebel, V. (2015). Experiences of high-ability high school students: A case study. Journal for the Education of the Gifted, 38(4), 428-446. https://doi.org/10.1177/0162353215607325 
Seedorf, S. (2014). Response to intervention: Teachers' needs for implementation in gifted and talented programs. Gifted Child Today, 37(4), 248-257. https://doi.org/10.1177/1076217514544029

Siam, K., \& Al-Natour, M. (2016). Teacher's Differentiated Instruction Practices and Implementation Challenges for Learning Disabilities in Jordan. International Education Studies, 9(12), 167-181. https://doi.org/10.5539/ies.v9n12p167

Smit, R., \& Humpert, W. (2012). Differentiated instruction in small schools. Teaching and teacher education, 28, 1152-1162. http://doi.org /10.1016/j.tate.2012.07.003

Smith, D. (2004). Introduction to special education ( $5^{\text {th }}$ ed.). Boston: Allyn \& Bacon.

Spencer-Waterman, S. (2014). Handbook on Differentiated Instruction for Middle \& High School. Abingdon, Oxon, UK: Routledge. https://doi.org/10.4324/9781315856230

Subban, P. (2006). Differentiated instruction: A research basis. International Education Journal, 7(7), 935-947.

Suprayogi, M. N., Valcke, M., \& Godwin, R. (2017). Teachers and their implementation of differentiated instruction in the classroom. Teaching and Teacher Education, 67, 291-301. https://doi.org/10.1016/j.tate.2017.06.020

Thakur, K. (2014). Differentiated instruction in the inclusive classroom. Research Journal of Educational Sciences, 2(7):10-14.

Tomlinson, C. A. (2005). Grading and differentiation: Paradox or good practice? Theory into Practice, 44(3), 262-269. https://doi.org/10.1207/s15430421tip4403_11

Tomlinson, C. A. (2001). What differentiated instruction is-and isnt. C Tomlinson (Ed.).

Tomlinson, C. A. (2002). Different learner's different lessons. Instructor, 112(2), 21-25.

Tomlinson, C. A., \& Imbeau, M. (2010). Leading and managing a differentiated classroom. Alexandria, Virginia: ASCD.

Tomlinson, C. A., \& Kalbfleisch, M. L. (1998). Teach me, teach my brain: A call fordifferentiated classrooms. Educational Leadership, 56(3), 52-55.

Tomlinson, C., \& Imbeau, M. (2012). Common Sticking Points: About Differentiation. School Administrator, 69(5), 19-22.

Tomlinson, C. A. (2004). Research evidence for differentiation. School Administrator, 61(7), 30.

Tucker, C. (2011). Differentiated instruction: What is it, Why is it important? How can technology help?

Walton, E. (2017). Inclusive education in initial teacher education in South Africa: practical or professional knowledge? Journal of Education, (67), 101-128.

Watts-Taffe, S., Broach, L., Marinak, B., McDonald Connor, C., \& Walker-Dalhouse, D. (2012). Differentiated instruction: Making informed teacher decisions. The reading teacher, 66(4), 303-314. https://doi.org/10.1002/TRTR.01126

Waxman, H. C., Alford, B. L., \& Brown, D. B. (2013). Individualized instruction. In Hattie, J. and Anderman, E. M. (Eds.). International Guide to Student Achievement. (pp. 405-407). NY: Routledge.

Wilujeng, N. C. S. (2012). The differentiated instruction and its implementation for developing countries: Partnership students learning Indonesian language in bridging course program. Journal of Education, 5(I), 49-52. https://doi.org/10.1109/ICEELI.2012.6360659.

Wolery, M., Holcombe, A., Venn, M. L., Brookfield, J., Huffman, K., Schroeder, C., Martin, C.J., \& Fleming, L. A. (1993). Mainstreaming in early childhood programs: Current status and relevant issues. Young Children, 49, $10,78-84$.

\section{Copyrights}

Copyright for this article is retained by the author(s), with first publication rights granted to the journal.

This is an open-access article distributed under the terms and conditions of the Creative Commons Attribution license (http://creativecommons.org/licenses/by/4.0/). 